
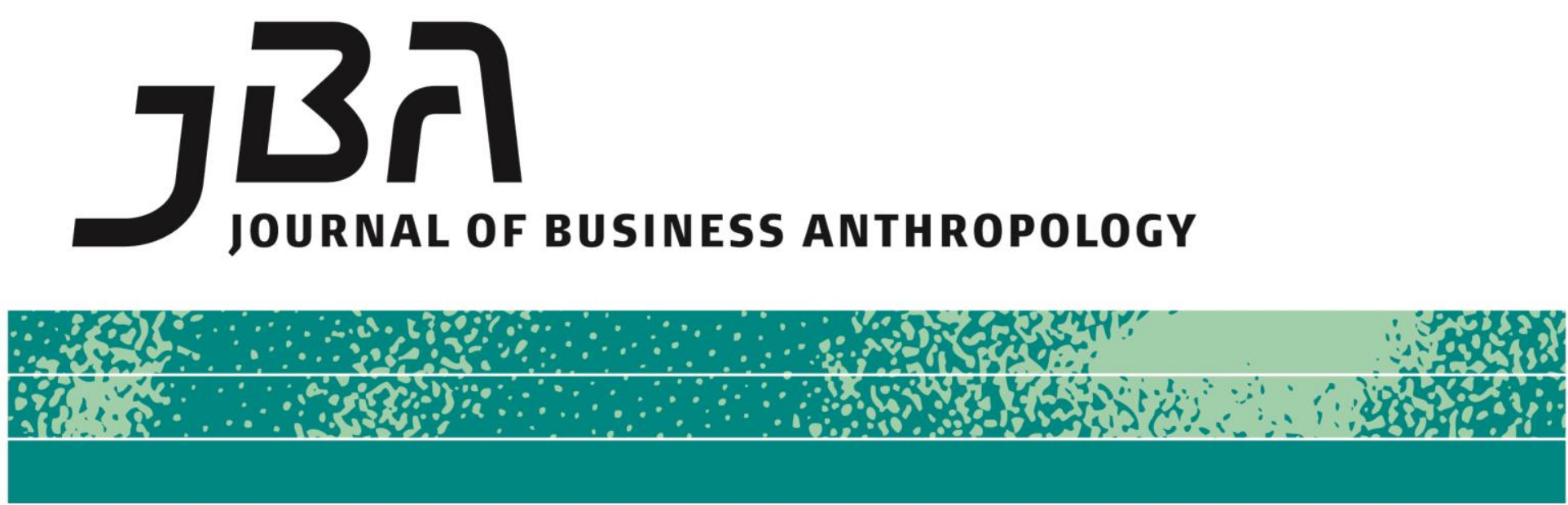

\title{
Musings on an Archaeology of Business Anthropology
}

\author{
Timothy de Waal Malefyt and Ghislaine Gallenga
}

Business anthropology is an emergent hybrid discipline (Baba 2006) that is still in the process of becoming (Ingold 2013). Even if this process is generally at work, temporal gaps are observed in its development, following national traditions. We thus observe differences between USA and Europe, probably in relation to the dichotomy between fundamental anthropology and applied anthropology, due to different colonial heritage. However, this hybrid discipline ostensibly bridges an anthropological focus with business, design, and organizational practices and beyond. The anthropologist's ability to "look beneath" apparent behavior and uncover deeper motivations, and link these insights to shared values and beliefs, is based on broader understandings of human behavior that organizations find useful. As obvious as this all may appear today, from the most unlikely or serendipitous of circumstances, a few pioneering adventurers in the1980s in the US and Europe began this enterprise first employed as business anthropologists.

These papers collected here reflect the thinking, wanderings, and adaptations of what are now prominent anthropologists, who at the time were pioneers in applying practices of observation, human group formation, and new digital technology to human behavior, and noting their influence on organizational structure and consumer markets in the business world. They trace their influence to the foundational works of other scholars, who explored materialist and capitalist concerns in the
Page 1 of 5

JBA 5(1): 1-5

Autumn 2016

(C) The Author(s) 2016 ISSN $2245-4217$

www.cbs.dk/jba 
meaning of goods (Douglas and Isherwood 1979), or innovators and entrepreneurs at work (Barth 1963; Rogers and Shoemaker 1971; Rogers 1962); questioned how and why consumers made choices in the global marketplace (Baran 1962); noted changing patterns of consumption among West African elites (Goody 1982); discussed the relationship between demand and supply on a global scale (Mintz 1979), or as an integrated world system (Wallerstein 1974).

The six papers (and two commentaries) that follow depart from these studies in their own applied ways, to inform an "archaeology" of the emergent discipline of Business Anthropology. They query why natives might prefer a popular sport shoe (Wilk and Arnould, in a paper written in 1984, but never previously published); they reflect on the ways they provoked ideas for advertising campaigns (Barnett); they inform us how woman led creative work in an all-male elite advertising club (Olsen); how they worked creatively as an American in a Japanese ad agency (McCreery); how itinerary wanderings led to the development of a successful business socio-anthropology in France (Desjeux); or pioneered approaches in the human use of emerging digital technologies (Anderson). These scholar-practitioners were the first to draw attention to the value and novelty of using anthropological theory in practice for what now seems self-evident. Since then, the world of anthropologists has vastly changed, but so, too, has the world of business.

The "turn" of events in anthropological approaches to the study of culture occurred when ideas of mass consumption of goods in the 1980 and 90s were viewed less as a detriment to culture and more as an enlightened outlook, which acknowledged consumption as the very means by which people expressed-and continue to express-creativity and diversity (Baba 2006). Anthropologist Daniel Miller $(1995,1997)$ contends that consumption is the contemporary means by which people express their cultural identities and relate to one another. Brian Moeran studied a Japanese advertising agency (1996), with new considerations for the social networks and liaisons afforded beyond capitalistic profit. All this coincided with novel views of consumer society and capitalistic business engagements, revealing how consumer agency and choice operate independently to act on, even to appropriate, consumption for constructive purposes.

From this perspective, consumers were worthy subjects of studyno longer passive dupes compelled by marketing messages, but "conceptualized as interpretive agents" who sought to form "lifestyles that defy dominant consumerist norms or that directly challenge corporate power" (Arnould and Thompson 2005: 875). Consumers were now seen to demonstrate creative choice and independence in interpreting consumption for their own use, such as using advertising as a positive force to create social bonds that reinforced togetherness through consumption ideals (Malefyt 2015). Indeed, even the consumption of 
goods-once seen as evidence of the conspicuous display of wealth (Veblen 2009) - was now seen as a contributing factor to fostering social interactions and strengthening personal bonds (Belk 1988; Douglas and Isherwood 1979). The marketing of goods offered consumers a way to engage people towards positive ends and "apprehend the world" (Sherry 1987: 442).

As anthropology changed, so did business. The increasing emphasis on interaction between consumers and corporations called for new forms of engagement. Marketing, for one, now shifts from product to consumer approaches, which place the consumer at the center of interactions (Edleman 2010). This has led to new forms of hybrid marketing that blur the boundaries of customer-corporation co-creation. As Nigel Thrift notes, "consumers are expected to make more and more extravagant investments in the act of consumption itself, through collecting, subscribing, experiencing and, in general, participating in all manner of collective acts of sense making" (Thrift 2005: 7). Daniel Miller suggests we reexamine the traditional divisions between consumption and production to ask: "what is a relationship?" (2007). In this we look at the complexity in relations between goods and people, and the multiple types of inter and intra-connections they create.

Anthropological views on consumption have also influenced marketing literature and marketing departments in business schools. Anthropologists and social theorists—such as Eric Arnould, Russell Belk, Grant McCracken, and John Sherry-forged a path for hybrid marketing studies from cultural and humanistic viewpoints. Accordingly, several new fields in the departments of marketing and consumer studies have recently emerged to redirect marketing as a positive force in society, and they have spawned new conferences, journals, and academic departments devoted to their inquiry. Two such groups evolved from the Association of Consumer Research using more humanistic and cultural methods for assessing consumption: Transformative Consumer Research (TCR) represents a movement within marketing organizations that seeks to encourage, support, and publicize research that benefits consumer welfare and improves quality of life for all persons affected by consumption across the world. For its part, Consumer Culture Theory (CCT) investigates consumer behavior from a decidedly social and cultural orientation, and includes a family of theoretical perspectives that address the dynamic relationships between consumer actions, the marketplace, and cultural meanings (Arnould and Thompson 2005). These approaches integrate insights from other disciplines and explore peoples' relations to material culture and each other in terms of making consumption more effective. From these mutual borrowings, other ways of practicing ethnography have been developed and evolved, in the same way as have anthropology and business. If one of the most important changes concerns the temporal dimension and the necessary adaptation of the long duration of the ethnographic survey, new ethnographic 
methods are developed more in line with the prerequisites of marketing: "blogging ethnography," for example (Minvielle and Wathelet 2014).

A convergence is also occurring in anthropology among the fields of cultural studies, organizational management, marketing, and consumer research, driven by practitioners and academics in search of new explanatory frameworks and managerial applications. Scholarly societies, academic journals, conferences, and professional organizations are rising, devoted to contemporary marketing and consumer behavior. The rise of NAPA (National Association for the Practice of Anthropology) reflects the increasing number of practicing anthropologists in the field of business and marketing; the emergence of Business Anthropology and two new scholarly journals-the Journal of Business Anthropology and the International Journal of Business Anthropology-along with EPIC (Ethnographic Praxis in Industry Conference), which is devoted to advancing the practice of ethnography in industry, all attest to the increased interest in investigating the effects of consumption and marketing on human behavior from anthropological and other humanistic perspectives.

The collection of papers in this issue of the $J B A$ informs the various challenges and clever solutions these early front runners managed, as they also inadvertently or purposefully set the stage for a radical convergence of business and anthropology that many of us benefit from today. It is because of these pioneers that we have and can discuss Business Anthropology as a discipline.

\section{References}

Arnould, Eric and Craig J. Thompson 2005 Consumer culture theory (CCT): twenty years of research. Journal of Consumer Research 31 (4): 868-882.

Baba, Marietta. L. 2006 Anthropology and business. In H. J. Birx (ed.), Encyclopedia of Anthropology. Thousand Oaks, CA: Sage.

Baran, Paul A. 1962 A Marxist View of Consumer Sovereignty. Monthly Review Press.

Barnet, Richard and Ronald Muller 1974 Global Reach. New York: Simon and Schuster.

Barth, Frederik (ed.) 1963 The Role of the Entrepreneur in Social Change in northern Norway. Oslo: Universitetsforlaget.

Belk, Russell 1988 Possessions and the extended self. Journal of Consumer Research 15 (2): 139-168.

Douglas, Mary and Baron Isherwood 1979 The World of Goods .New York: Basic Books. 
Edleman, Daniel 2010. Branding in the digital age: You're Spending Your Money in All the Wrong Places. Harvard Business Review 88 (12): 62-69.

Goody, Jack 1982 Cooking, Cuisine and Class: A Study in Comparative Sociology. Cambridge: Cambridge University Press.

Ingold, Tim 2013 Making: Anthropology, Archaeology, Art and Architecture. New York: Routledge.

Malefyt, Timothy de Waal 2015 Relationship advertising: how advertising can enhance social bonds. Journal of Business Research 68: 2494-2502.

Miller, Daniel 1995 Acknowledging Consumption. London: Routledge.

----- 1997 Capitalism: An Ethnographic Approach. Oxford: Berg.

----- 2007 What is a relationship? Is kinship negotiated experience? Ethnos 72(4): 535-554.

Minvielle, N. and Wathelet, O. 2014 Enhancing design and innovation practices through "blogging ethnography." 13th Marketing Trends Conference. Universita Ca' Foscari, Venezia, Jan 25, 2014.

Mintz, Sidney 1979 Time, sugar and sweetness. Marxist Perspectives 2: 5673.

Moeran, Brian 1996 A Japanese Advertising Agency: An Anthropology of Media and Markets, Honolulu: University of Hawaii Press.

Rogers, Everett M. and F. Floyd Shoemaker 1971 Communication of Innovations: A Cross Cultural Approach. New York: Free Press.

Rogers, Everett M. 1962 Diffusion of Innovations. New York: Free Press.

Sherry, John, F. Jr. 1987 Advertising as a cultural system. In J. UmikerSebeok (ed.), Marketing and Semiotics, New Directions in the Study of Signs for Sale, pp. 441-461. New York: Mouton de Gruyter.

Thrift, Nigel 2005 Knowing Capitalism. London: Sage.

Veblen, Thorsten 2009 The Theory of the Leisure Class. Oxford: Oxford University Press.

Wallerstein, Immanuel 1974 The Modern World System. New York: Academic Press. 